\title{
Correction to: Mini-transverse incision using a novel bush-hook versus conventional open incision for treatment of carpal tunnel syndrome: a prospective study
}

Tianxiao Ma', Dongyue Wang ${ }^{1}$, Yuqing $\mathrm{Hu}^{1}$, Xiaocui Zhao ${ }^{1}$, Wei Wang ${ }^{2^{*}}$ and Lihua Song ${ }^{1 *}$

Correction to: J Ortho Surg Res. 16, 462 (2021)

https://doi.org/10.1186/s13018-021-02608-x

Following the publication of the original paper [1], the authors found out that the affiliations have been incorrectly captured. Updated information is provided in the affiliation section above.

The original article has been corrected.

Published online: 14 September 2021

\section{Reference}

1. Ma T, Wang D, Hu Y, Zhao X, Wang W, Song L. Mini-transverse incision

using a novel bush-hook versus conventional open incision for treatment of carpal tunnel syndrome: a prospective study. J Orthop Surg Res. 2021;16:

462. https://doi.org/10.1186/s13018-021-02608-x.

The original article can be found online at https://doi.org/10.1186/s13018021-02608-x

*Correspondence: wangweiydsy1@163.com; slh9536@126.com

${ }^{2}$ Department of Orthopaedic Surgery, Xiangjiang Area of the Third Hospital of Hebei Medical University, Shijiazhuang, Hebei, People's Republic of China 'Department of Orthopaedic Surgery, The General Hospital of Jizhong Energy Xingtai Mining Group, No.202 Bayi Street, Xingtai, Hebei, People's Republic of China

C C The Author(s). 2021 Open Access This article is licensed under a Creative Commons Attribution 4.0 International License, which permits use, sharing, adaptation, distribution and reproduction in any medium or format, as long as you give appropriate credit to the original author(s) and the source, provide a link to the Creative Commons licence, and indicate if changes were made. The images or other third party material in this article are included in the article's Creative Commons licence, unless indicated otherwise in a credit line to the material. If material is not included in the article's Creative Commons licence and your intended use is not permitted by statutory regulation or exceeds the permitted use, you will need to obtain permission directly from the copyright holder. To view a copy of this licence, visit http://creativecommons.org/licenses/by/4.0/ The Creative Commons Public Domain Dedication waiver (http://creativecommons.org/publicdomain/zero/1.0/) applies to the data made available in this article, unless otherwise stated in a credit line to the data. 